\title{
Impact of Fiscal Policies in Western Balkan SMEs' Growth: Evidence from Kosovo
}

\author{
Gezim Jusufi \\ University of Prishtina, Kosovo \\ gezimi.gjilan@gmail.com \\ http://orcid.org/0000-0003-4338-3331 \\ Fillorete Gashi-Sadiku \\ University of Prishtina, Kosovo \\ fillorete.ga@gmail.com \\ https://orcid.org/0000-0001-6240-7285
}

Received: 2. 8. 2020

Accepted: 22. 10. 2020

\section{ABSTRACT}

This paper analyses the impact of fiscal policies on increasing the capacity of SMEs from the manufacturing sector in the Western Balkans, with particular emphasis on those in Kosovo. To achieve empirical results, the data obtained from the opinions of the 100 analysed SMEs were processed through logistic regression. The SPSS statistical software was also used for these statistics. Based on literature review and empirical results, it has been concluded that fiscal policies have an impact on Kosovo SMEs growth. Also in Kosovo and in other Western Balkan countries, fiscal policies and packages have been adopted to support SMEs and have had a significant effect on their activities. Despite the fact that under normal circumstances fiscal support for SMEs has been provided by the governments of these countries, in the near future there should be greater fiscal support to SMEs by means of fiscal incentives due to the devastating effects of the COVID 19 pandemic on each country's economy.

Keywords: fiscal policies, Western Balkans, SMEs, capacity growth, logistic regression

JEL: H2O, H3O, H32 


\section{Introduction}

The Western Balkans is a geopolitical term and covers six countries which are in the process of accession to the EU (British Council, 2018; Jusufi and Ukaj, 2020). This six countries are: Albania, North Macedonia, Bosnia and Herzegovina, Kosovo, Montenegro and Serbia (Jusufi and Lubeniqi, 2019). Except for Albania, all other countries in this region have been part of Yugoslavia. According to Bartlett and Prica (2016) Western Balkans countries can be referred to as the "Super Periphery" of the European Union (EU). As a result of the bitter past, these countries have suffered greatly. Therefore, The European Union (EU) has contributed to the integration and regional reconciliation of these countries in order to achieve social and economic development through different programmes (Tošović-Stevanović and Ristanović, 2016; Ajdarpašić and Qorraj, 2019). This multiyear investment of the European Union (EU) has influenced the increase of administrative, human and financial capacities of the countries of this region (Ajdarpašić and Qorraj, 2020). Table 1 presents the economic indicators of the countries of this region.

Table 1: Main economic indicators of Western Balkan countries in 2017

\begin{tabular}{|c|c|c|c|c|c|c|}
\hline Indicators & ALB & B\&H & KOS & NMAC & MNE & SRB \\
\hline $\begin{array}{l}\text { Population } \\
\text { (million) }\end{array}$ & 2.87 & 3.50 & 1.83 & 2.08 & 0.62 & 7.02 \\
\hline $\begin{array}{l}\text { Nominal GDP at current prices } \\
\text { (EUR billion) }\end{array}$ & 11.58 & 15.29 & 6.41 & 10.06 & 4.30 & 39.18 \\
\hline $\begin{array}{l}\text { GDP per capita PPP } \\
\text { (constant } 2011 \text { international \$) }\end{array}$ & 11802 & 11731 & 9780 & 13132 & 16465 & 14049 \\
\hline $\begin{array}{l}\text { Unemployment } \\
\text { (\% of total active population) }\end{array}$ & 14.1 & 20.5 & 30.5 & 22.4 & 16.4 & 13.5 \\
\hline $\begin{array}{l}\text { Services, value added } \\
\text { (\% of GDP) }\end{array}$ & 47.5 & 55.7 & 45.8 & 54.6 & 59.1 & 50.0 \\
\hline $\begin{array}{l}\text { Industry (including construction), } \\
\text { value added (\% of GDP) }\end{array}$ & 20.9 & 23.9 & 25.6 & 24.1 & 15.9 & 26.4 \\
\hline $\begin{array}{l}\text { Forestry, agriculture and } \\
\text { fishing, value added (\% of GDP) }\end{array}$ & 19.0 & 5.6 & 9.1 & 7.9 & 6.8 & 6.0 \\
\hline $\begin{array}{l}\text { Employment in services sector } \\
\text { (\% of total employment) }\end{array}$ & 41.1 & 48.7 & n/a & 53.8 & 74.3 & 56.6 \\
\hline $\begin{array}{l}\text { Employment in industry } \\
\text { (\% of total employment) }\end{array}$ & 18.6 & 32.2 & n/a & 29.8 & 18.0 & 24.4 \\
\hline $\begin{array}{l}\text { Employment in agriculture } \\
\text { (\% of total employment) }\end{array}$ & 40.3 & 19.1 & n/a & 16.4 & 7.6 & 19.0 \\
\hline
\end{tabular}

Source: OECD et al. (2019) 
The market of these countries of this region is small and is largely influenced by developments in global markets (Qorraj, 2018). None of the Western Balkan countries can be considered to have a functioning market economy because it does not have the competitive ability to compete in the world market (Holzner and Schwarzhappel, 2018; Jusufi and Bellaqa, 2019). According to Qorraj and Jusufi (2019) entrepreneurs in these countries have limited access to working capital along with limited managerial and technical expertise. Also the inadequate educational system is one of the causes of economic and social stagnation of region where unemployment rates are very hight (Vidovic et al., 2011; Jusufi and Ajdarpašić, 2020).

The global financial crisis has affected the countries of this region more than other world countries and the European average. The reasons for this are the low level of development of the financial system of these countries (Erić and Stošić, 2012). Whereas, restrictive monetary and fiscal policies have been used to achieve macroeconomic stability (Lorena, 2010) but the results in the reform of the economy and the public sector as well as of public institutions are insufficient. These problems continue to be challenges for this region in the future (Osmani, 2016, p. 6). The process of political and economic transformation in this region is based on the development of the private sector in particular on the development of entrepreneurial activities. Also creating a favorable environment for doing business for SMEs. However, the problems that these SMEs face are: Insufficient financial support, non-supportive tax system for SMEs, inadequate and insufficient institutional support (Džafić et al., 2008).

European Charter for Small Enterprises package has been endorsed also by the Western Balkan countries consist of ten key areas to which these countries are required to focus and harmonize their support for SMEs:

1. Proper education and professional training for entrepreneurs;

2. Faster and cheaper and start-ups;

3. Better system of legislation and regulation;

4. Availability of skills;

5. Improving access to the Internet system;

6. Not just single market but also many markets;

7. Financial and taxation matters;

8. Strengthen the technological capacity of small enterprises;

9. Successful e-models and top-class small business support;

10. Develop stronger, more effective representation of small enterprises' interests at national and EU level (Bartlett et al., 2005).

SMEs in WB are not in the best competitive position especially with regard to the international market, taking into consideration their limited capabilities, such as higher transaction costs, adaption costs, low level of technology, and low level of cooperation with international SMEs (Qorraj and Jusufi, 2018). For a long time SMEs did not have fiscal support from public institutions due 
to ethnic conflicts fuelled further by expansionary fiscal and monetary policies related to the military conflicts (Uvalić and Cvijanović, 2018). Internal conflicts in the countries of this region have weakened public sector and justice institutions, weakening public confidence in the rule of law (Chapman et al., 2008).

The institutions of these countries, like those of the EU, constantly reformed their tax system by reducing tariffs, redefining tax bases and making changes and clarifications in the interpretation of existing laws. Simultaneously with the reduction of tax levels, the level of deductions and exemptions from taxes was reduced, as a counter-refund for the reduction of tax rates (Krešić et al., 2017, p. 8; Peci, 2013, p. 75; Syka and Kaduku, 2013, p. 150). Value added $\operatorname{tax}$ (VAT) is the main source of tax revenue for WB governments. One of the reasons for this is that corporate income tax rates and personal income tax rates are relatively low following widespread adoption of flat tax reforms. Governments of these countries implement policies for the development and growth of SMEs such as reduction of taxes by $65 \%$ if $1-10$ new jobs are created; $70 \%$ if $10-99$ new jobs are created; $75 \%$ if at least 100 new jobs are created (Bartlett et al., 2017). Also some of the countries of this region have created special economic zones to attract foreign investors (Krasniqi et al., 2019). In these areas international companies will not pay any taxes. These zones are particularly pronounced in Serbia, North Macedonia and Bosnia and Herzegovina. Details regarding the type of taxes applied in the Western Balkan countries are presented in Table 2. Table 2 presents basic data on the type and level of taxes in the 6 countries of the Western Balkans. It should be noted that no country applies anymore the only standard VAT rate, except the Bosnia and Herzegovina, where the tax policy has not changed so much in the last five years. So as can be seen, all of these countries have applied different tax levels in most cases. 
Impact of Fiscal Policies in Western Balkans SMEs' Growth: Evidence from Kosovo

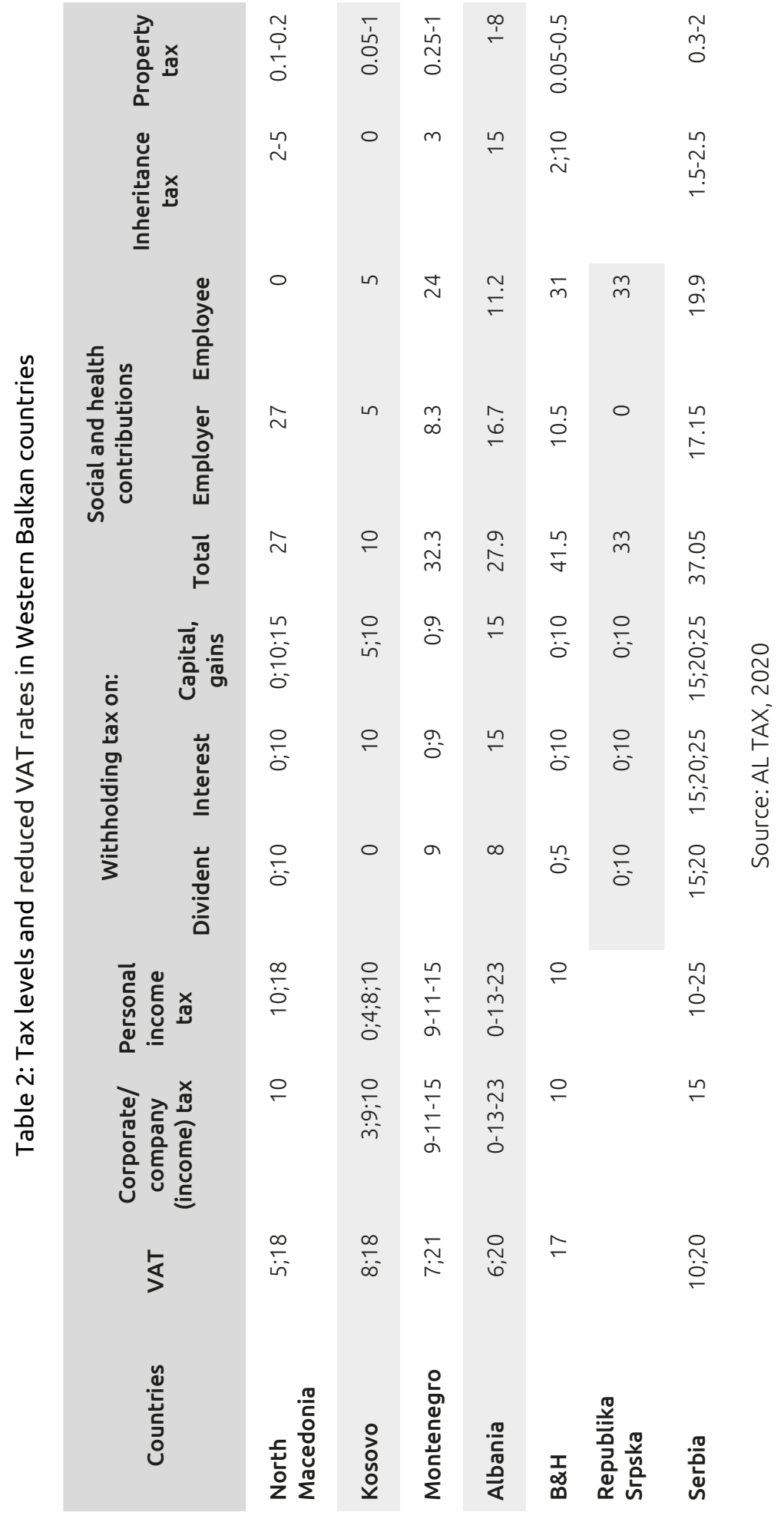


Meanwhile Table 3 presents the data related to the economic freedom of the Western Balkan countries. From the following figures it can be understood that these countries are approximately similar in terms of economic freedom.

Table 3: Index of economic freedom in Western Balkan countries

\begin{tabular}{|lrrr|}
\hline \multicolumn{1}{c}{ WB Countries } & Tax Burden & Government spending & Fiscal health \\
\hline Albania & 85.9 & 74.6 & 86.3 \\
\hline Bosnia and Herzegovina & 83.6 & 49.3 & 97.3 \\
\hline Kosovo & 92.6 & 76.5 & 94.0 \\
\hline Montenegro & 85.4 & 32.1 & 23.4 \\
\hline North Macedonia & 91.5 & 71.0 & 87.7 \\
\hline Serbia & 83.7 & 49.7 & 94.1 \\
\hline
\end{tabular}

Source: 2020 index of economic freedom

Recently some WB countries have improved their fiscal sustainability by creating fiscal buffers. This enabled these countries to fund larger support programs. But the region entered the COVID-19 pandemic crisis with more debt than before the 2009 financial crisis. Borrowing needs to increase interest payments across the region as fiscal deficits and rising public debt and tightening financial markets. After overcoming the pandemic, fiscal policy must ensure a balance between supporting the economic recovery and ensuring the fiscal sustainability of these countries (World Bank Group, 2020, p. 1).

In the following sections the literature review will be done. The literature review will include the characteristics of WB SMEs, a summary of fiscal policies, and the impact of fiscal policies on various economic indicators of developing countries. Then the empirical analysis will be presented, specifically the results of the logistic regression. At the end will be presented the conclusions reached and the confirmation of the raised hypotheses.

\section{Literature review}

\subsection{SMEs sector in Western Balkans}

SMEs as economic entities act as catalysts for rapid change and restructuring of the economy in response to changing economic and social conditions ( $\mathrm{Gi}$ urcă and Popa, 2010, p. 1; Ruchkina et al. 2017, p. 260). Over the last decade in the Western Balkans region it has been realized that SMEs have an important role to play in the transition process. Of all the types of businesses, SMEs dominate the economies of the Western Balkan region (Džafić et al., 2007, p. 2). The graph 1 shows the number of SMEs per 1000 inhabitants in this region. 
Graph 1: SMEs per 1000 inhabitants in WB region

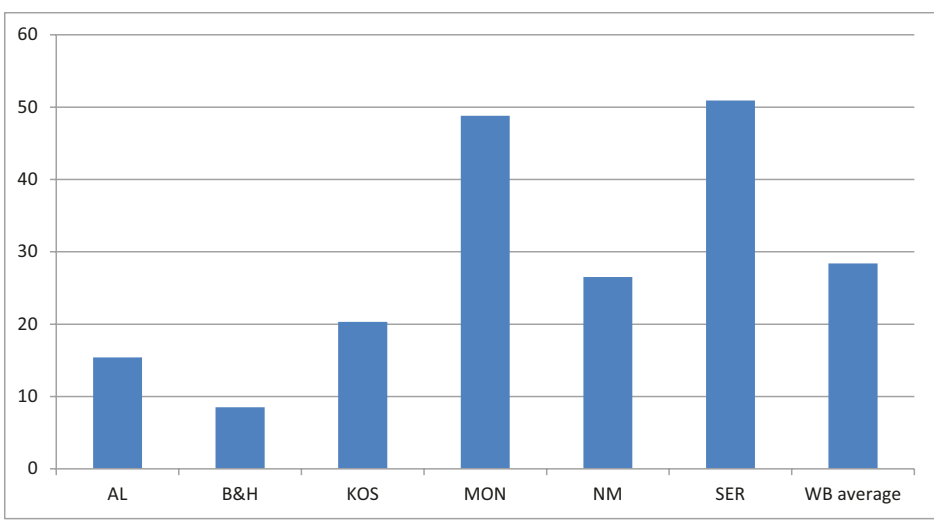

Source: OECD et al. (2019)

According to Sanfey and Milatovic (2018), SMEs make up about 99\% of businesses in this region. SMEs offer jobs for three quarters of the total number of employees, ranging from just under $70 \%$ in Bosnia and Herzegovina to more than $80 \%$ in Albania. On average, SMEs add one third of the annual value added of countries. This proportion is similar to the EU average, ranging from just over $50 \%$ in Serbia to just under $70 \%$ in Albania. Therefore, successful SMEs are of great importance to the economies of developing countries or transition economies. Krasniqi and Tullumi (2013) concentrated on a few sets of variables which influence the success of SMEs: Psychological traits, personality, managerial skills and training of entrepreneurs and the external environment. Instinct for independence, innovative orientation, risk attitude, competitive nature, mastery of business skills, availability of capital, previous experience and family support all have an impact on success (Kadriu et al., 2019, p. 401). The total number of SMEs in this region can be seen from the data in the Table 4.

Table 4: Number of SMEs and their share in Western Balkans total firms number

\begin{tabular}{|lcl|}
\hline \multicolumn{1}{|c}{ Country } & $\begin{array}{c}\text { Number of } \\
\text { SMEs }\end{array}$ & Share \\
\hline Albania & 44,173 & $99.66 \%$ \\
\hline Bosnia and Herzegovina & 29,743 & $99.12 \%$ \\
\hline Kosovo & 37,115 & $99.86 \%$ \\
\hline Montenegro & 30,238 & $99.84 \%$ \\
\hline North Macedonia & 55,055 & $99.73 \%$ \\
\hline Serbia & 357,234 & $99.85 \%$ \\
\hline
\end{tabular}

Source: OECD et al. (2019) 
Rehman et al. (2019) analyzed barriers to growth of WB SMEs. The region has great potential for growth and development of SMEs, especially those in the service sector. Within the services sector, retail and wholesale have the highest percentage of SMEs. Public institutions must play a crucial role in improving the conditions that promote better performance for SMEs. The tax system and the improvement of the regulatory environment should also be simplified. Access to finance is a significant factor that determines the growth of SMEs. Therefore, there must be adequate access to finance.

Properly educated workforce is a problem. This workforce must be trained. The most important role of government in this regard is to educate society at all levels of education to practice entrepreneurship. There should be a general policy coordination in this region, so that all measures taken result in a better performance of SMEs. Also according to Nizaeva and Coşkun (2018) there should be effective government policies aimed at increasing SMEs' access to external financing. SMEs need to rely on the following areas to combat slow growth: Credit facilitation, business support services, technology services, entrepreneurship skills and development, and specific initiatives (Bekefi, 2006, p. 13; Leitner, 2015).

From this sub-section it can be concluded that SMEs are of great importance for the economic development of many countries, especially the Western Balkans. Despite this, the number of SMEs in this region is still small and there is no capacity to alleviate unemployment and ensure overall well-being for this region. Also, the SME sector faces many different challenges and problems that hinder the normal development of this sector, which is so vital for the economy of region.

\subsection{Fiscal policy and SMEs growth}

There is a lot of research on the impact of fiscal policies on economic growth and SME growth of developing countries. However, there is a lack of literature on the impact of fiscal policies on SMEs of the Western Balkans, especially those of Kosovo. According to Korkmaz et al. (2019) there is a positive and significant impact of indirect taxes on economic growth of developing countries, and a negative and significant impact of direct taxes both in the short run and the long run. Taxation is also one of the main tools of governments to influence the enterprise with the aim of increasing its profit (European Commission, 2017, p. 5). Osmani (2014) analyzed fiscal decentralization as a way to achieve effectiveness in the economic system. In Western Balkans, the process of political and financial decentralization has had many shortcomings because this decentralization has not been analyzed from a functional point of view, but from an ethnic point of view. Examples are Bosnia and Herzegovina, North Macedonia and Kosovo. Easterly and Rebelo (1993) analyzed empirically the effect of fiscal policy on economic growth and evidences support a strong association between the development level of the country and the fiscal structure. In developing countries, international trade taxes are important, while in developed economies, income taxes are a priority. Fiscal policy is 
influenced by the scale of the economy, measured by its population, investment in transport and communication is consistently correlated with growth. Therefore, the effects of the tax are difficult to assess empirically.

According to Alves (2019) different fiscal policies can have a decided impact on investment decisions of different SMEs. If the government imposes lower taxes on individual income, this could lead to increased aggregate demand for durable and non-durable goods. This brings higher profits and offers new investment opportunities. When the government decides to change corporate tax rates, this affects several sectors. In particular, tax benefits may lead to specialization in higher value-added economic activities for the economy. Moreover, tax raises in property and social security contributions reduce consumption. These tax policies affect the movement of interest rates. This promotes companies' investment decisions. Beca and Nişulescu-Ashrafzadeh (2014) has achieved similar results. Meanwhile Zhllima et al. (2013) emphasize that VAT reduction and excise exemption is very important for agricultural products such as greenhouses. Also Lešnik et al. (2018) confirms that the tax gap is reduced in conditions of economic growth.

The role that fiscal policy should play in promoting economic stabilization has changed in the last decade as a result of conditions and advances in economic research. Auerbach (2017) using a variety of valuation strategies for different countries and different time periods, has suggested that multipliers can be large for both tax and cost changes, and that the effects can be improved during periods of economic slowdown. Taxation in general deals with transferring a part of profits earned in one jurisdiction to the state budget of that jurisdiction (Grubišić and Ćevizović, 2008, p. 115). Balseven and Tugcu (2017) analyzed the impact and role of fiscal policy on the welfare and income of certain countries. Tax revenues alleviate income inequality in developing countries while social benefits alleviate income inequality in developed countries. Also, economic growth has a negative impact on income distribution in developing countries, while economic growth and inflation have a positive impact on income distribution in developed countries.

When public debt does not exceed the present value of the expected primary budget surpluses we have fiscal sustainability. Shevchuk and Kopych (2018) support fiscal policy aimed at increasing government revenues combined with cuts in public sector spending, in case the current policies are not sufficient to achieve fiscal sustainability. Any attempt to lower the interest rate and stimulate output growth from an expansionary monetary stance is likely to be counterproductive in the presence of significant public external debt at risk of exchange rate misuse. Ćorić et al. (2015) asserted that only coordinated monetary and fiscal expansion can stimulate economic growth in developing countries without compromising exchange rate stability. Both expansionary policies have positive effects on economic activity while the effects on the nominal exchange rate are in the opposite direction. In volatile conditions, public institutions need to implement more prudent fiscal policies in the expansive phase of the business cycle, to stimulate growth in 
future economic slowdowns. The budget is a framework for expenditures on income and expenditures for one year. It defines policies and programs aimed at achieving government development objectives. Oke (2013) states that government should try to include more capital expenditures in that budget to accelerate the recording of an annual increase in the value of the growth process brought about by the future effect of capital investments.

Fiscal deficit is a problem that many countries face. As a result of expansionary fiscal policies, the fiscal deficit has increased significantly in developing economies. Tung (2018) showed that in all periods the fiscal deficit had a negative effect on the economic growth of developing countries. Policymakers need to make greater efforts to reduce spending. The public budget is not spent to maintain a large state-owned sector because government spending on this sector causes a prolonged budget deficit. The government should generate more revenue from domestic tariffs and taxes, which are obtained from luxury products and services from foreign countries. Similar results have been achieved by Velnampy and Achchuthan (2013). If government institutions aim to implement more effective fiscal policies that would be a useful part of investment policy, it is essential to provide tax law entrepreneurs with the security of using tax incentives that they can understand without much effort and extra risk. in their interpretation and implementation of the business. Thus, the sustainability of the implemented fiscal policy is ensured (Bogovac and Hodžić, 2014, p. 68).

Ezejiofor et al. (2015) concluded that taxation as an element of fiscal policy has a significant impact on the performance of SMEs. The performance of SMEs determines the amount of tax to be paid. Governments should be sensitive to changes in taxes and other macro-environmental elements, enabling productive sectors to adapt to the dynamic environment. Another study conducted by Eze and Ogiji (2013) claims that government expenditure have positive and significant effect on manufacturing sector output, while government revenue have negative and significant impact on manufacturing sector. The result also reveals that there is longrun relationship between fiscal policy and manufacturing sector output, as evidenced by the co-integration. Augustine and Asiedu (2017) reached a significant impact of monetary policy on the performance of SMEs in terms of employment growth. Despite the high interest rates, SMEs that manage to reduce lending rates have a higher growth in terms of employment. Fiscal policy in terms of tax perceptions is less related to the performance of SMEs. To empower SMEs, relevant institutions need to constantly monitor the financial system in order to minimize the large spread of lending in an environment with high rates. Atawodi and Ojeka (2012) studied the impact of tax policy on SME growth. Tax regulations should be simplified in order to facilitate the activity of SMEs. Tax administrators need to perform their duties more efficiently with integrity. This solves the problem of multiple taxes. SME owners should also be educated on tax payment issues.

Kukanja and Planinc (2018) analyzed the efficiency of SMEs in Slovenia after the government's implementation of fiscal cash registers. Revenue growth was achieved as a result of fiscal cash registers. This increased the efficiency 
of financial data. Tee et al. (2016) asserted that changes in tax rates lead to changes in the prices of goods and services. Increasing tax rates cause higher costs of production, distribution and sales. These increase prices and with rising prices change consumer behaviors. People buy fewer products as a result of high prices. Whenever prices rise due to rising tax levels, the level of consumption falls and this affects the development of SMEs. Paying taxes reduces the purchasing power of an SME because a large amount of money raised is used to pay taxes instead of SME growth.

The results of Gbande et al. (2018) show that major determinants of SMEs growth are policies directed on tax rate reduction and stability, and government expenditure on infrastructure targeting. The policy insinuation therefore, is that fiscal policy should be set in such a way that the objective it wants to achieve is clearly and transparently defined in response to the dynamics of the domestic and global economic developments. The government should maintain its expenditure on infrastructural developments, as this will have a multiplier effect on the growth of SMEs activities and enhance the overall economic growth. Gupta et al. (2013) claim that among economic environment factors fiscal policies affect SMEs growth. Meanwhile Yusuph and Youze (2014) emphasize that the government should provide basic fiscal and monetary conditions for SME development, such as political stability, favorable macroeconomic conditions in terms of low inflation and a real exchange of interest and interest rates, low levels of import protection in the sense of the absence of quantitative restrictions and relatively low uniform tariffs and an efficient legal system. Policy instruments and support measures at the national sector and at the SME level should be well addressed and classified into three types: Enticement Policies, Supply-side policies and Bunch Policies.

According to Sivalingam and Bhaskaran (2005) VAT could lead to new investment opportunities for SMEs because in case many products inclusive of VAT costs is more to consumers in a location far away from the place of manufacturer as a result of value added by transportation, storage and trade chain margins, this would make it attractive for entrepreneurs to start a production facility near the last point of consumption and gain a share of the existing market. Mach (2018) analyzed VAT rates and their impact on business and tax revenue and he emphasizes that reducing a tax rate which is higher than the revenue maximizing rate would be good for everybody.

Manzo (2011) claims that the productivity growth of SMEs is more sensitive to changes in the corporate tax rate than that of larger and older firms. The reasons for this are not immediately clear although they suggest that this could be due to the difficulties that SMEs have in accessing debt finance. According to Wadesango et al. (2018) the self-assessment system requires constant education of taxpayers, as there are always new emerging laws and revision of tax legislation. Other factors that affect SMEs in compliance are the speculations of corruption within those charged with governance on the use of tax monies, the lack of transparency on public sector funds raises a negative attitude towards tax. 
Other issues that affect SMEs on complying through Self-assessment system are complexity of the tax legislation and as previously stated the economic environment is a probable cause for tax evasion. The complexity of tax legislation has caused SMEs to fail in the application of exemptions and other benefits such as capital allowances, wear and tear and allowable deductions. A tax incentive grant to SMEs encourages a positive attitude towards tax and encourages SME growth and public funds transparency is also to be considered. Matarirano et al. (2019) studied impact of tax compliance costs on business performance. According to their findings internal tax compliance costs were found to have the heaviest burden on small businesses, and thus had the strongest impact on performance. External tax compliance costs were found to have a negative effect on business performance. These authors recommend proper tax planning for small businesses to enjoy the benefits associated with tax compliance costs. To improve on their performance, small businesses are advised to undertake tax tasks in-house.

The study of Pope and Abdul-Jabbar (2008) has shown that the most important policy area that should be addressed is to recognize fully the compliance burden of the SMEs at the national level. Accordingly, establishment of relevant committees, similar to the Beddall Committee and the Small Business Deregulation Task Force in Australia, involving all relevant parties, relevant SMEs organizations, tax professionals and academics, is recommended. Feyitimi et al (2016) claim that tax incentives are germane to the growth, development and continued sustenance of SMEs. Tax incentives play a vital role in ensuring that SMEs thrive. There was a significant correlation between taxation and SMEs' growth. The study recommends that there should be a friendly tax policy for all startup businesses preferably a tax holiday, or an introduction of a growth limit which can be said to be a level stable enough to sustain tax payment. Also Twesige and Gasheja (2019) in their study emphasize that there was a strong positive and significant relationship between tax incentives and the growth of SMEs. The study concluded that tax incentives are the key to the sustainable growth of SMEs. The government should design policies that specifically address issues related to the sustainable growth of SMEs.

Mungaya et al. (2012) studied the effect of tax incentives on SMEs growth and SMEs which are not registered cannot benefit from the tax incentives. The many SMEs that operate in the informal sectors cannot benefit from growth incentives. The findings of the study also show that SMEs that have not prepared books of accounts and payroll summaries as they have a small number of employees cannot benefit from tax incentives. The same applies to SMEs whose owners are business employees, who do not take into account the principle of business as a separate entity from the owner and employment status. Due to this fact the tax imposed on them is based on approximations which may not reflect the true picture of business' turnover. As a result, the business may be charged a huge amount of tax compared to what it would probably pay if books of accounts and payroll summaries were maintained. 


\section{Tax policy and system in Kosovo}

Having in mind that Kosovo is transitioning from a socialist, centrally-planned economy to a capitalist, market economy, with a decade of existence as a parallel ineffective state, a devastating conflict in between the transition, and a half-decade rule of international community where the primary concern were human rights, it is not surprising that tax policies and their effect have not been a priority for researchers. In terms of tax incentives, it can be argued that other than basic tax incentives import tax exemptions and VAT exemptions for a few goods and services, there are no major tax incentives foreseen in the Kosovo laws. Recent developments regarding free economic zones are preceding changes in tax incentives. Tax rates in Kosovo are low compared to other countries in the region or in Europe but Kosovar manufacturers still find them to be high, mainly because they operate in an environment where the cost of doing business is already high. They are thus driven to informality, which among other adverse effects, such as lower opportunities to get credit, also makes them vulnerable to tax officials' arbitrariness and extortion, creates conditions that are conducive for unfair competition, and further increases their cost of doing business (Ministry for Foreign Affairs of Finland \& UNDP, 2014).

In Kosovo creators of tax policy in 2009 did a reduction of tax norms in two main forms of direct taxes, Corporate Income Tax (CIT) from 20\% to 10\% and Personal Income Tax (PIT) from 0\%, 5\%, $10 \%$ and $20 \%$ to $0 \%, 4 \%, 8 \%$ and $10 \%$. At CIT, the aim was through reduction of tax norm, to increase the competition capacity of Kosovo vis-à-vis Foreign Direct Investments, respectively CIT norm to be harmonized in the level of existing norms of CIT that were already existing in Western Balkan countries. At the case of PIT creator's aim was to achieve another objective, that of fighting fiscal evasion, respectively attracting tax subjects so that by stimulating with tax burden they move from subjects of gray economy to subjects that manage to carry out their tax obligations. At the increase of VAT norm from $15 \%$ to $16 \%$ designers had fiscal intentions, respectively the aim was to be done the compensation of public incomes that would be lacking along with decreasing of tax norms of CIT and PIT.

On September 2015, the amendments to the Law No. 05/L-037 on Value Added Tax (VAT) entered into force. The standard rate is 18\% (previously 16\%). This represents a $50 \%$ decrease from the initial standard rate of $16 \%$. Considering the importance of VAT on budget revenues, in order to make up for the lost revenues with the introduction of the reduced rate, the Draft Law on VAT foresees an increase of the standard rate from 16 to $18 \%$ for all other remaining categories. In the meantime, the rate of $0 \%$ is applied to exports with the aim of stimulating export-oriented firms. At VAT, creator's aim was that through reduced rate of $8 \%$ tax policy to be more in realizing social equality. Except decreasing of tax norms, Kosovo has applied few numbers of tax incentives to CIT in order to simulate foreign investors. Tax incentives mainly are related to CIT. Therefore, Kosovo in comparison to the compared countries, it very little applies tax incentives, by making tax policy and tax system in this segment not being in function of economic development (Peci 2016). 
Through the variable Impact of the tax administration we have tried to analyze the impact of the institution of tax administration on the business activity of SMEs. So how effective are the activities of this institution in increasing the functionality of the analyzed SMEs. From descriptive statistics it can be understood that this institution is often effective in performing its tasks towards SMEs. While this variable does not represent significance in logistic regression. According to World Bank Report (2014) Kosovo institutions need to strengthen the tax administration by developing the quality of tax inspectors, improving risk assessment modules, stepping up efforts to combat tax evasion, and increasing random audits to assess areas for improvement in risk assessments. To better understand Kosovo's tax system we can rely on the data in the Table 5.

Table 5: Tax types in Kosovo

\begin{tabular}{|c|c|c|}
\hline Tax type & $\begin{array}{l}\text { Turnover } \\
\text { threshold }\end{array}$ & Tax rate \\
\hline Value Added Tax- VAT & $30000 \mathrm{E}$ & $8 \%$ and $18 \%$ \\
\hline $\begin{array}{l}\text { Corporate Income Tax- CIT } \\
\text { Manufacturing, trading and } \\
\text { transporting industry, etc } \\
\text { Service industry }\end{array}$ & under 50000 Euro & $\begin{array}{l}3 \% \\
9 \%\end{array}$ \\
\hline $\begin{array}{l}\text { Personal Income Tax- PIT } \\
\text { Manufacturing, trading and } \\
\text { transporting industry, etc } \\
\text { Service industry }\end{array}$ & under 50000 Euro & $\begin{array}{l}3 \% \\
9 \%\end{array}$ \\
\hline Corporate Income Tax- CIT & over $50000 \mathrm{E}$ & $10 \%$ \\
\hline $\begin{array}{l}\text { Personal Income Tax- PIT } \\
\text { Annual income from } 0 \text { to } 960 \\
\text { Annual income from 960- } 3000 \\
\text { Annual income from 3000- } 5400 \\
\text { Annual income from } 5400 \text { and over }\end{array}$ & over $50000 \mathrm{E}$ & $\begin{array}{r}0 \% \\
4 \% \\
8 \% \\
10 \%\end{array}$ \\
\hline $\begin{array}{l}\text { Tax on wages (monthly) } \\
\text { Annual income from } 0 \text { to } 80 \\
\text { Annual income from } 80-250 \\
\text { Annual income from } 250-450 \\
\text { Annual income from } 450 \text { and over }\end{array}$ & & $\begin{array}{r}0 \% \\
4 \% \\
8 \% \\
10 \%\end{array}$ \\
\hline Tax on rents, interests and Royalties. & & $10 \%$ \\
\hline Tax on special categories & & $3 \%$ \\
\hline Tax on non-residents & & $5 \%$ \\
\hline
\end{tabular}

Source: Tax Administration of Kosovo (2020) 
The Government of Kosovo made a number of decisions for fiscal adjustment. Among other things, these decisions are related to the approval of new drafts:
a. Value Added Tax (VAT);
b. Corporate Income Tax;
c. Personal Income Tax.

Under Article 6 of the Draft Law on VAT, the threshold of VAT is reduced of 50 $000 €$ as current law is $30000 €$. So any business that performs turnover over $30000 €$ per year, will be obliged to register for VAT and pay the portion that exceeds this amount. Budget would benefit from this reduction in the VAT threshold because a greater number of businesses will be obliged to pay VAT. This fiscal policy will burden the new businesses and small businesses, especially those services that have lesser levels of supplies. It is exactly the new businesses that need fiscal incentives and which potentially create new jobs. VAT is charged with the standard rate of $18 \%$. Notwithstanding paragraph 1 of this Article, the reduced VAT rate is calculated and paid $8 \%$ for the supply of goods and services, as well as their import (Statovci and Asllani, 2017).

In addition to these decisions, Fiscal package 2.0 has been approved by the government of Kosovo in 2017 and provides tax exemptions for new businesses, from three to seven years, depending on the amount invested and the number of employees. We have tried to get the opinions of Kosovo SMEs regarding the effects of this package through Impact of fiscal package 2.0 variable. Most of the surveyed SMEs stated that this package has had a positive impact on their business activity. This variable is significant. The last variable is Fiscal policy functionality through which we have tried to obtain the opinions of SMEs analyzed on the functionality of fiscal policy. A large number of SMEs analyzed stated that fiscal policies in Kosovo are functional so they are at the service of businesses. Also the results of logistic regression show that this variable has a positive relationship with the dependent variable. So the more functional the fiscal policies in Kosovo, the more the capacities of SMEs will increase.

Asllani (2011), Asllani et al. (2020) claims that Kosovo's budgetary sustainability requires improvements in tax collection and administration processes, an increase in fiscal culture, the establishment of a complete, advanced and enforceable legal framework, better definition and full implementation of policy good government in terms of budget expenditures, elimination of corruptive phenomena, very good control of the movement of goods at the border and within the country and a continuous reduction of the informal economy and tax evasion. All this will enable better quality revenue collection, thus ensuring the growth of SMEs. According to Kryeziu (2019) one of the objectives of the tax policy norms in Kosovo, is to continuously improve and design tax system. Whereas, as far as trade relations between states are concerned, the primary purpose of this policy is to make efforts to harmonize taxes at EU level, as the pronounced difference in tax rates can break down and 'regulate market competition at EU level. In addition to the improvements made, the countries of the Western Balkans also face many challenges in terms of fiscal 
policy. The Table 6 is a summary of the challenges and recommendations to be made by the institutions of the Western Balkan countries.

Table 6: Challenges and policy recommendations of fiscal policies in Western Balkan countries

\begin{tabular}{|c|c|c|}
\hline Country & Challenges & Recommendations \\
\hline Albania & $\begin{array}{l}\text { High debt and financing needs, } \\
\text { heavily dependent on banks }\end{array}$ & $\begin{array}{l}\text { Fiscal consolidation largely } \\
\text { through revenue measures and } \\
\text { phasing out energy subsidies }\end{array}$ \\
\hline$B \& H$ & $\begin{array}{l}\text { Balance the need for further } \\
\text { fiscal } \\
\text { consolidation with supporting } \\
\text { growth; composition of } \\
\text { spending }\end{array}$ & $\begin{array}{l}\text { Contain current, non-disaster } \\
\text { related spending, notably } \\
\text { wages and benefits; improve } \\
\text { the quality of public spending; } \\
\text { continue ongoing efforts to } \\
\text { improve revenue collection and } \\
\text { administration }\end{array}$ \\
\hline Kosovo & $\begin{array}{l}\text { Safeguard fiscal sustainability, } \\
\text { arrest the worsening } \\
\text { composition of the budget }\end{array}$ & $\begin{array}{l}\text { Wage and benefit moderation; } \\
\text { improve tax compliance; shift tax } \\
\text { policy gradually towards } \\
\text { domestically collected taxes }\end{array}$ \\
\hline $\begin{array}{l}\text { North } \\
\text { Macedonia }\end{array}$ & $\begin{array}{l}\text { Rebuild buffers and safeguard } \\
\text { sustainability of public } \\
\text { finances and the exchange } \\
\text { rate peg }\end{array}$ & $\begin{array}{l}\text { Fiscal consolidation embedded in a } \\
\text { comprehensive spending review }\end{array}$ \\
\hline Montenegro & $\begin{array}{l}\text { High and rising debt, } \\
\text { preserving market access }\end{array}$ & $\begin{array}{l}\text { Fundamental expenditure reform } \\
\text { on pension system and public } \\
\text { sector wages }\end{array}$ \\
\hline Serbia & $\begin{array}{l}\text { High debt, increasing debt } \\
\text { dynamics }\end{array}$ & $\begin{array}{l}\text { Ambitious and sustained fiscal } \\
\text { adjustment through wages and } \\
\text { pensions, reducing state aid to } \\
\text { weak state-owned } \\
\text { enterprises }\end{array}$ \\
\hline
\end{tabular}

Source: IMF 2015, 108

Abdixhiku et al. (2018) claim the importance of institutional elements and the tax rate. Slow reforms, high corruption and high tax rates reduce the amount of taxes paid by SMEs to transition economies. In these economies, government reforms are key to combating tax evasion. According to BSC Kosovo (2013), It is assumed that in Kosovo about 50\% of turnover is not declared by businesses to the tax authorities. Despite this, tax collection has improved as a result of stricter control by tax administration officials. Therefore, based on these data, it can be said that the tax administration has a tremendous impact on the functionality and effectiveness of fiscal policies and the fiscal system in developing countries. Asllani (2015) claims that Kosovo has a poor 
collection of the incomes. Mostly dominate border taxes (excise, customs fees, VAT) with tendency to fall down slowly and beside this a symbolic increase of internal taxes. The intention of government policy should be oriented in the collection of the taxes inside the country not to be collected at the border. Certainly to achieve the objective in collection of the incomes within the economy the country, needs time and to build institutional and economic capacities. Also, at the local level should be done more not only in the most incredibly completion in the field of harmonization of legislation but should increase the efficiency even in cases of collection of funds and also should be done the fiscal decentralization. Another important component is the issue of government spending, as those costs burden the budget and where they are oriented.

\section{Methodology And Data}

Empirical research has involved the collection of data using survey. The process of data collection took place between November 2019 and March 2020. We analyzed 100 Kosovo manufacturing SMEs that currently operate in Kosovo market. The target audience, focus on CEOs, and production managers of manufacturing SMEs in all regions of Kosovo. The interview of the respondents lasted 50 minutes. Due to the nature of the empirical problem, faceto-face interviews were conducted. We selected data for these SMEs from Ministry of Trade and Industry of Kosova. In logistic regression the dependent variable has two categories 1 and 0 . Like ordinary regression, logistic regression can include some independent variables, which can be quantitative or qualitative. The logistic regression model can be written as follows:

$$
\operatorname{logit}(p)=a+b_{1} x_{1}+b_{2} x_{2}+\ldots+b_{i} x_{i}(1)
$$

Logistic regression makes it possible to understand the impact of the dependent variable on the independent variables. The suitability of the formulated model can be assessed using several methods (Bewick et al., 2005)

The logistic regression equation is as follow:

$P\left(Y_{i}=1\right)=\left(\beta_{0}+\beta_{1}\right.$ Business duration $+\beta_{2}$ Education background $+\beta_{3}$ taxes + $+\beta_{4}$ Impact of the tax administration $+\beta_{5}$ Impact of fiscal package $2.0+$ $+\beta_{6}$ Fiscal policy functionality $+\varepsilon_{i}(2)$ 
Table 7: Variables of logistic regression

\begin{tabular}{|c|c|}
\hline Dependent variable & Variables descriptions and measurement \\
\hline Capacities growth & 1- if the capacities increased, 0 -otherwise \\
\hline Independent variables & Variables descriptions and measurement \\
\hline Business duration & $\begin{array}{l}1 \text { to } 5 \text { years (reference category), } 1.6 \text { - } 10 \text { years, } 2.11 \\
\text { - } 15 \text { years, } 3.16 \text { - } 20 \text { years, } 4.20+\text { years }\end{array}$ \\
\hline Education background & $\begin{array}{l}\text { Low (reference category), 1.Secondary, 2. High, } \\
\text { 3. Master of science level employee, 4. PhD level } \\
\text { employee. }\end{array}$ \\
\hline $\begin{array}{l}\text { Impact of taxes on business } \\
\text { constrain }\end{array}$ & $\begin{array}{l}\text { Never (reference category), 1.Rarely, 2.Sometimes, } \\
\text { 3.Often, 4.Always }\end{array}$ \\
\hline $\begin{array}{l}\text { Impact of the tax } \\
\text { administration }\end{array}$ & $\begin{array}{l}\text { Never (reference category), 1.Rarely, 2.Sometimes, } \\
\text { 3.Often, 4.Always }\end{array}$ \\
\hline Impact of fiscal package 2.0 & 1-Yes, 0-otherwise \\
\hline Fiscal policy functionality & 1-Yes, 0-otherwise \\
\hline & Source: own calculations \\
\hline \multicolumn{2}{|c|}{$\begin{array}{l}\text { The model will be tested to determine if there is a relationship between the } \\
\text { fiscal package } 2.0 \text { and SMEs capacity growth, as well as tax constraint and } \\
\text { SMEs capacity growth. Therefore, the hypotheses of this paper will be: }\end{array}$} \\
\hline \multicolumn{2}{|c|}{ H1: No relationship between tax constraint and SME capacity growth; } \\
\hline \multicolumn{2}{|c|}{ H2: Positive relationship between fiscal package 2.0 and SME growth. } \\
\hline \multicolumn{2}{|c|}{$\begin{array}{l}\text { H3:Tax administration has a positive impact on the functionality of fiscal poli- } \\
\text { cies in developing countries such as Kosovo. }\end{array}$} \\
\hline \multicolumn{2}{|c|}{$\begin{array}{l}\text { SME capacity growth is the dependent variable. There is a lack of research } \\
\text { that has used sales as a dependent variable to measure SME growth. SME } \\
\text { growth is associated with strong survival and achievement of organizational } \\
\text { goals (Rexhepi Mahmutaj and Krasniqi, 2020, p. 30). The dependent variable } \\
\text { is capturing period of } 2015-2019 \text {. SME representatives were asked if their ca- } \\
\text { pacities had increased during this period. } 68 \text { of the surveyed SMEs answered } \\
\text { that YES have increased their capacities, while the rest answered that NO } \\
\text { their capacities have not increased. }\end{array}$} \\
\hline
\end{tabular}

\section{Results}

The Table 8 presents the descriptive statistics for each analyzed variable. So in this table are presented the answers of the representatives of the analyzed SMEs. 
Impact of Fiscal Policies in Western Balkans SMEs' Growth: Evidence from Kosovo

Table 8: Descriptive statistics

\begin{tabular}{|c|c|}
\hline Variables & Frequency \\
\hline \multicolumn{2}{|l|}{ SME capacities growth } \\
\hline 1- if the capacities increased & 68 \\
\hline 0-otherwise & 32 \\
\hline \multicolumn{2}{|l|}{ Business duration } \\
\hline 1 - 5 years & 11 \\
\hline $6-10$ years & 26 \\
\hline $11-15$ years & 28 \\
\hline $16-20$ years & 20 \\
\hline $20+$ years & 15 \\
\hline \multicolumn{2}{|l|}{ Education background } \\
\hline Low & 6 \\
\hline Secondary & 39 \\
\hline High & 45 \\
\hline Master of science level employee & 8 \\
\hline PhD level employee & 2 \\
\hline \multicolumn{2}{|l|}{ Impact of taxes as business constrain } \\
\hline Never & 10 \\
\hline Rarely & 5 \\
\hline Sometimes & 44 \\
\hline Often & 36 \\
\hline Always & 4 \\
\hline \multicolumn{2}{|l|}{ Impact of the tax administration } \\
\hline Never (reference category) & 1 \\
\hline Rarely & 13 \\
\hline Sometimes & 7 \\
\hline Often & 49 \\
\hline Always & 30 \\
\hline \multicolumn{2}{|l|}{ Impact of fiscal package 2.0} \\
\hline Yes & 61 \\
\hline Otherwise & 39 \\
\hline \multicolumn{2}{|l|}{ Fiscal policy functionality } \\
\hline Yes & 84 \\
\hline Otherwise & 16 \\
\hline
\end{tabular}

Source: own calculations 
The Table 9 shows the data or results from the logistic regression. Their comments will show what impact each independent variable has on the dependent variable or on increasing the production capacity of the analyzed SMEs.

Table 9: Logistic regression results

\begin{tabular}{|c|c|c|c|c|c|c|}
\hline Variables & B & $\begin{array}{l}\text { Std. } \\
\text { Error }\end{array}$ & Wald & $d f$ & Sig. & $\operatorname{Exp}(B)$ \\
\hline \multicolumn{7}{|l|}{ Business duration } \\
\hline \multicolumn{7}{|l|}{1 - 5 years (reference category) } \\
\hline $6-10$ years & 1.167 & 1.046 & 1.222 & 1 & 0.068 & 0.954 \\
\hline 11 - 15 years & 1.230 & 0.566 & 1.296 & 1 & $0.042^{* *}$ & 1.023 \\
\hline $16-20$ years & 1.165 & 0.423 & 1.185 & 1 & 0.091 & 0.951 \\
\hline $20+$ years & 1.241 & 0.863 & 1.327 & 1 & 0.085 & 2.032 \\
\hline \multicolumn{7}{|l|}{ Education background } \\
\hline \multicolumn{7}{|l|}{ Low (reference category) } \\
\hline Secondary & -1.006 & 0.556 & 1.185 & 1 & 0.062 & 1.942 \\
\hline High & 1.422 & 0.423 & 1.369 & 1 & 0.058 & 0.133 \\
\hline Master of science level employee & 1.216 & 0.359 & 2.066 & 1 & 0.126 & 1.011 \\
\hline PhD level employee & 1.365 & 0.502 & 2.455 & 1 & 0.143 & 0.627 \\
\hline \multicolumn{7}{|l|}{ Impact of taxes as business constrain } \\
\hline \multicolumn{7}{|l|}{ Never (reference category) } \\
\hline Rarely & 1.158 & 1.006 & 1.533 & 1 & 0.679 & 1.039 \\
\hline Sometimes & 1.237 & 1.036 & 1.452 & 1 & $0.023 * *$ & 0.827 \\
\hline Often & 1.697 & 1.569 & 2.036 & 1 & 0.593 & 0.648 \\
\hline Always & 1.324 & 1.098 & 1.556 & 1 & 0.752 & 0.863 \\
\hline \multicolumn{7}{|l|}{ Impact of the tax administration } \\
\hline \multicolumn{7}{|l|}{ Never (reference category) } \\
\hline Rarely & 1.235 & 1.023 & 2.552 & 1 & 0.094 & 0.956 \\
\hline Sometimes & -1.558 & 0.856 & 2.435 & 1 & 0.103 & 0.639 \\
\hline Often & 1.654 & 0.795 & 1.221 & 1 & 0.087 & 1.236 \\
\hline Always & 1.698 & 1.033 & 1.563 & 1 & 0.076 & 1.498 \\
\hline Impact of fiscal package 2.0 & 2.356 & 1.008 & 2.030 & 1 & $0.047 * *$ & 3.569 \\
\hline Fiscal policy functionality & 1.876 & 0.963 & 1.783 & 1 & 0.075 & 1.911 \\
\hline
\end{tabular}

Notes: **significant at $5 \%$. Source: Own calculations. 
The first category 1 to 5 years of the first variable business duration is reference category. This category will not be included in the logistic regression calculations. While other categories of this variable will be compared with the reference category. Categories 6 to 10 years and 16 to 20 years are in negative relation to the reference category because their values are (0.954) and (0.951). With the increase of these values, the production capacities of SMEs decrease. 11 to 15 years' category is significant category. Gashi (2014) has achieved similar results in terms of business experience or duration of Kosovo SMEs.

As for Education background variable low education level category is reference category. High and PhD level employee categories are in negative relation with reference category. As the values of these categories increase, the influence of the reference category decreases. The more these SMEs hire employees with higher education the more the number of employees with lower level of education will decrease. The average salary in Kosovo ranges from 350 to 450 Euros. The trend of the salaries has been increasing 5 to 10 percent during the last three years, and this trend is being expected to further increase in the coming years. An obstacle regarding employee recruitment is that of low qualified applicants in the field of food engineering. Therefore, in most of the SMEs outsource food-engineering experts from EU countries or from other neighboring countries. Another problem that SMEs face when recruiting and hiring new employees is considered the low willingness and low interest of youth for handicraft work (Riinvest Institute, 2016, p. 49).

Regarding Impact of taxes as business constrain variable, most SMEs (44) have declared that taxes sometimes pose a problem for their business activity. This category is also significant. Based on the responses of SMEs and the results of logistic regression, it can be said that taxes do not pose a major problem for the development of business activities in Kosovo. But this only applies to normal conditions, because in the current conditions where COVID 19 has hit the economy of every country hard, it cannot be said that taxes do not pose a major problem for SMEs. In the current conditions, SMEs are not carrying out normal activities and this will affect the payment of taxes. There is lack of research on the impact of tax rates or tax incentives on private sector investments and economic development in Kosovo. The lack of consistent, detailed and reliable data in Kosovo has made any such efforts difficult or even impossible. Kosovo has undergone a process of institution-building only recently and has only now started to accumulate tax records or enterprise surveys that can be used to build longer time series and analyze trends.

\section{Conclusion}

Fiscal policies are very significant for general development of all countries. Through them, social equality is achieved, the development of enterprises through their support by easing taxes and fees, etc. From the literature review it can be claimed that the countries of the Western Balkans have made considerable efforts to formulate fiscal policies in line with the contemporary needs of business and other stakeholders. Many reforms have been made 
which have been requested by the EU institutions, with the aim of bringing the fiscal policies of this region closer to those of the EU. All this was done during the process of integration of these countries into the EU. Harmonization of fiscal policies is one of the key elements that enables faster integration of these six countries in the EU.

This region has similar economic indicators. Therefore, the empirical evidence obtained from the analysis of Kosovo SMEs can be applied to other countries, simply a comparison sample can be taken for further studies. Our first hypothesis is No relationship between tax constraints and SME capacity growth and based on the results achieved, it can be said that tax-related barriers or tax constraints are not a major barrier to the business activity of these SMEs. So the level of taxes in Kosovo does not hinder SMEs much to carry out their business activities. However, despite this result, it can be said that in the near future as a result of the crisis caused by COVID 19 taxes will be a major barrier to the development of business activities in Kosovo and other Western Balkan countries.

Our second hypothesis is Positive relationship between fiscal package 2.0 and SME growth, which can be proved to be accurate because it is significant and has a positive relationship with the dependent variable SME capacity increase. This package has had a positive role on the business activity of SMEs in Kosovo. Similar packages have been adopted in other countries of the Western Balkans, so any initiative taken by public institutions for fiscal relief is very beneficial for businesses in each sector. Despite the positive results, it is recommended that in the near future due to the crisis by COVID 19, the countries of the Western Balkans adopt special fiscal packages aimed at supporting SMEs to overcome the economic and financial consequences of this pandemic. In Western Balkan countries there are many fiscal and public policies aimed at increasing SMEs and expanding their business activity, but so far there have been very few such studies that have researched their effect on SMEs. Therefore, the added value of this paper lies in the research of such an important topic for the financial sustainability of these countries.

As for our last hypothesis Tax administration has a positive impact on the functionality of fiscal policies in developing countries such as Kosovo, it can be said that the tax administration plays an important role in this regard. Therefore, the more organized and legally strong this administration is, the more effective will be the fiscal policy and its instruments in developing countries. This assertion is also supported by the empirically obtained data of our paper. 


\section{References}

Abdixhiku, L. et al. (2018). Business Tax Evasion in Transition Economies: A Cross-Country Panel Investigation. The European Journal of Comparative Economics, 15 (1), p. 30. At <http://ejce.liuc.it/18242979201801/1824297920 18150102.pdf>, accessed 30 June 2020.

Ajdarpašić, S. and Qorraj, G. (2019). Does University Performance Matter for EU Programmes in South East Europe: Case Study HORIZON 2020. Management: Journal of Contemporary Management Issues, 24 (2), pp. 1-10. At <https:// hrcak.srce.hr/index.php?show=clanak\&id_clanak_jezik=324050>, accessed 25 July 2020.

Ajdarpašić, S. and Qorraj, G. (2020). The Impact of the EU Programs in the Western Balkans, InterEULawEast: Journal for the International and European Law, Economics and Market Integrations, 7 (1), pp. 65-88. At <https://hrcak.srce.hr/index.php?show=clanak\&id_clanak_jezik=348824>, accessed 27 July 2020.

AL TAX. (2020). Taxation Trends in Western Balkans, 2020: A Comparative View of Taxation and Legal Framework for Businesses and Individuals in 6 Western Balkan Countries. $2^{\text {nd }}$ Edition. At <https://papers.ssrn.com/sol3/papers. cfm?abstract_id=3637612>, accessed 3 August 2020.

Alves, J. (2019). The impact of tax structure on investment: An empirical assessment for OECD countries, Public Sector Economics, 43 (3), pp. 291-309. At <http://www.pse-journal.hr/upload/files/pse/2019/3/4.pdf>, accessed 1 August 2020.

Asllani, G. (2011). The Impact of Fiscal Policy to the Kosovo Economical Development. Acta Universitatis Danubius, 7 (1), pp. 136. At <https://www. researchgate.net/publication/227409937_The_Impact_of_Fiscal_Policy_to_ the_Kosovo_Economical_Development>, accessed 1 August 2020.

Asllani, G. (2015). Complexity of fiscal policy in Kosovo and their treatment. Academic Journal of Business, Administration, Law and Social Sciences, 1 (2), pp. 168-172. At <https://www.researchgate.net/publication/333223675 Complexity_of_fiscal_policy_in_Kosovo_and_their_treatment>, accessed 1 August 2020.

Asllani, G. et al. (2020). A Study of Kosovo's Fiscal Policies and Tax System: Key Issues to Align with European Standards, Özen, E. and Grima, S. (Ed.) Uncertainty and Challenges in Contemporary Economic Behaviour (Emerald Studies in Finance, Insurance, and Risk Management), Emerald Publishing Limited, pp. 273-284. At <https://www.emerald.com/insight/content/ doi/10.1108/978-1-80043-095-220201018/full/html>, accessed 2 August 2020.

Atawodi, W.O. and Ojeka, A.S. (2012). Relationship between Tax Policy, Growth of SMEs and the Nigerian Economy. International Journal of Business and Management, 7 (13), pp. 125-133. At <http://www.ccsenet.org/journal/ index.php/ijbm/article/view/14024>, accessed 26 July 2020.

Auerbach, J.A. (2017). Fiscal Policy, PIIE, pp. 1-26. At <https://www.piie.com/ system/files/documents/auerbach20171012paper.pdf.>, accessed 21 July 2020.

Augustine, O. and Asiedu, E. (2017). Monetary Versus Fiscal Policy Effects on SMEs Growth in Africa: Evidence from Ghana. International Research Journal of Finance and Economics, pp. 164, 7-22. At <http://www. 
internationalresearchjournaloffinanceandeconomics.com/ISSUES/ IRJFE_164_01.pdf>, accessed 21 July 2020.

Balseven, H. and Tugcu, T.C. (2017). Analyzing the Effects of Fiscal Policy on Income Distribution: A Comparison between Developed and Developing Countries, International Journal of Economics and Financial Issues, 7(2), pp. 377-383. At <https://www.econjournals.com/index.php/ijefi/article/ view/4235>, accessed 20 July 2020.

Bartlett, W. and Prica, I. (2016). Interdependence between Core and Peripheries of the European Economy: Secular Stagnation and Growth in the Western Balkans. LSE and University of Belgrade, LEQS Paper No. 104, p. 1. At <https://papers.ssrn.com/sol3/papers.cfm?abstract_id=2729882>, accessed 11 July 2020.

Bartlett, W. et al. (2005). Institutions, Entrepreneurship Development and SME Policies in South East Europe. Enterprise in Transition: 6th International Conference Proceedings, edited by B. Crnjak-Karanovic, Split: Faculty of Economics. At <https://www.researchgate.net/profile/Nevenka_Cuckovic/ publication/38176587_Institutions_entrepreneurship_development_and SME_policies_in_South_East_Europe/links/02e7e524d40a217d14000000/ Institutions-entrepreneurship-development-and-SME-policies-in-South-EastEurope.pdf>, accessed 18 July 2020.

Bartlett, W. et al. (2017). Study on Special Economic Zones (SEZs) in the Western Balkans, Directorate-General for Neighbourhood and Enlargement Negotiations (DG NEAR), Final report $-2^{\text {nd }}$ revised version. At <https:// www.researchgate.net/profile/Besnik_Krasniqi/publication/321156818_ Study_on_Special_Economic_Zones_SËZs_in_the_Western_Balkans/ links/5be8d657299bf1124fcc2828/Study-on-Special-Economic-Zones-SEZs-inthe-Western-Balkans.pdf>, accessed 19 July 2020.

Beca, M. and Nişulescu-Ashrafzadeh, I. (2014). The effects of the fiscal policy on the SMEs sector in Romania during the economic crisis. Procedia Economics and Finance, 15, pp. 334-341. At <https://www.sciencedirect.com/science/ article/pii/S221256711400519X>, accessed 10 July 2020.

Bekefi, T. (2006). Tanzania: Lessons in building linkages for competitive and responsible entrepreneurship. UNIDO and Kennedy School of Government-Harvard University. At <https://www.unido.org/sites/default/ files/2009-03/69451_CSRI_09_0.pdf>, accessed 8 July 2020.

Bewick, V. et al. (2005). Statistics review 14: Logistic regression. Critical Care, 9 (1), pp. 112-117. At <https://www.researchgate.net/publication/8038704_ Statistics_review_14_Logistic_regression>, accessed 13 July 2020.

Bogovac, J. and Hodžić, S. (2014). Fiscal Policy led by Tax Incentives: Croatian Experiences. Naše gospodarstvo/Our Economy, 60 (1-2), pp. 62-71. At <http:// www.ng-epf.si/index.php/ngoe/article/view/77>, accessed 11 July 2020.

British Council. (2018). Cultural Skills research summary: Examining the cultural skills gaps and shortages in the Western Balkans, p. 7. At <https://www. britishcouncil.org/sites/default/files/h086_02_culturalskillsunit_western_ balkans_final_web_1.pdf>, accessed 30 June 2020 .

Business Support Centre (BSC) Kosovo. (2013). Research Report: Entrepreneurship and Small Business Development in Kosovo in 2012, p. 27. At <https://bsckosovo.org/en/2013/01/28/entrepreneurship-and-smallbusiness-development-in-kosovo-in-2012-2/>, accessed 19 June 2020.

Chapman, N. et al. (2008). Regional Programme Evaluation: Western Balkans, DFID, Evaluation Report EV693, pp. 1-73. At <https://assets.publishing. 
service.gov.uk/government/uploads/system/uploads/attachment_data/ file/67744/ev693.pdf>, accessed 28 June 2020.

Ćorić, T. et al. (2015). Monetary and fiscal policy mix in a small open economy: The case of Croatia, Economic Research-Ekonomska Istraživanja, 28 (1), pp. 407-419. At <https://hrcak.srce.hr/index.php?show=clanak\&id_clanak_ jezik=253056https://hrcak.srce.hr/index.php?show=clanak\&id_clanak_ jezik=253056>, accessed 27 July 2020.

Džafić, Z. et al. (2007). Development oF SMEs Sector in the Western Balkan countries. Economic research- Ekonomska istraživanja, 20 (1), pp. 72-82. At <https://hrcak.srce.hr/21480>, accessed 14 July 2020.

Džafić, Z. et al. (2008). Development of Small and Medium Enterprises: B\&H compared to other Western Balkans Countries, Economic analysis, 41 (12), pp. 88-103. At <http://ebooks.ien.bg.ac.rs/297/1/2008_1_2_06.pdf.>, accessed 19 July 2020.

Easterly, W. and Rebelo, S. (1993). Fiscal policy and economic growth: An empirical investigation. Journal of Monetary Economics, 32 (3), pp. 417-458. At <https://www.sciencedirect.com/science/article/abs/ pii/030439329390025B>, accessed 1 July 2020.

Erić, D. and Stošić, I. (2012). Development of the European Financial System: Challenges for the Balkan Countries Integration Process. Institute of Economic Sciences. Book Chapters, in: Paulino Teixeira \& António Portugal Duarte \& Srdjan Redzepagic \& Dejan Eric (ed.), European Integration Process in Western Balkan Countries, 1 (6), pp. 114-143. At <https://ideas.repec. org/h/ibg/chaptr/euinpro-6.html>, accessed 12 July 2020.

European Commission. (2017). Literature review on taxation, entrepreneurship and collaborative economy. Taxation Papers, WORKING PAPER No 70. At <https://ec.europa.eu/taxation_customs/sites/taxation/files/taxation_ paper_70.pdf >, accessed 12 July 2020.

Eze, O.R. and Ogiji, F.O. (2013). Impact of Fiscal Policy on the Manufacturing Sector output in Nigeria: An Error Correction Analysis. International Journal of Business and Management Review (IJBMR), 1(3), pp. 35-48. At <http:// www.eajournals.org/wp-content/uploads/IMPACT-OF-FISCAL-POLICYON-THE-MANUFACTURING-SECTOR-OUTPUT-IN-NIGERIA-AN-ERRORCORRECTION-ANALYSIS1.pdf>, accessed 31 July 2020.

Ezejiofor, A.R. et al. (2015). Tax as a Fiscal Policy and Manufacturing Company's Performance as an engine for Economic growth in Nigeria. European Journal of Business, Economics and Accountancy, 3(3), pp. 1-9. At <http://www. idpublications.org/wp-content/uploads/2015/03/TAX-AS-A-FISCAL-POLICYAND-MANUFACTURING-COMPANY\%E2\%80\%99S-PERFORMANCE-AS-ANENGINE.pdf>, accessed 24 July 2020.

Feyitimi, O. et al. (2016). Tax Incentives and the Growth of Small and Medium Scale Enterprises in Developing Economy - The Nigerian Experience. European Journal of Research and Reflection in Management Sciences, 4(2), pp. 25-42. At <https://www.researchgate.net/publication/341314435 TAX_INCENTIVES_AND_THE_GROWTH_OF_SMALL_AND_MEDIUM_SCALE_ ENTERPRISES_IN_DEVELOPING_ECONOMY_-THE_NIGERIAN_EXPERIENCE/ link/5eba8d83299bf1287f7ffeb0/downloads, accessed 26 July 2020.

Gashi, P. (2014). Human Capital and Export Decisions: The Case of Small and Medium Enterprises in Kosovo. Croatian Economic Survey, 16 (2), pp. 91-120. At <https://hrcak.srce.hr/index.php?show=clanak\&id_clanak_jezik=194570>, accessed 2 July 2020. 
Gbande, C. et al. (2018). Effect of Fiscal Policy on growth of Small- Medium scale enterprises in Nigeria. Sahel Analyst: Journal of Management Sciences, 16 (4), pp. 122-139. At <https://www.researchgate.net/publication/338484108_ EFFECT_OF_FISCAL_POLICY_ON_GROWTH_OF_SMALL_MEDIUM_SCALE_ ENTERPRISĒS_IN_NIGERIA>, accesssed 9 July $20 \overline{2} 0$.

Giurcă Vasilescu, L. and Popa, A. (2010). Financing Measures for supporting European SMEs during crisis. Agricultural Management/Lucrari Stiintifice Seria I, Management Agricol, 12 (3), At <http://eds.b.ebscohost.com/ eds/pdfviewer/pdfviewer?vid=0\&sid=694a65c5-9625-45ad-b2131c63c4861375\%40pdc-v-sessmgr06>, accessed 19 July 2020.

Grubišić, M. and Ćevizović,l. (2008). Business Group Taxation in Croatia and the Implications of the EU Framework Adoption. Zagreb International Review of Economics \& Business, SCl (1), pp. 113-135. At <https://hrcak.srce.hr/78672>, accessed 28 July 2020.

Gupta, D.P. et al. (2013). Firm growth and its determinants. Journal of Innovation and Entrepreneurship, 2(15), pp. 1-14. At <https://innovationentrepreneurship.springeropen.com/articles/10.1186/2192-5372-2-15>, accessed 17 July 2020.

Holzner, M. and Schwarzhappel, M. (2018). Infrastructure Investment in the Western Balkans: A firs analysis. European Investment Bank \& Vienna Institute for International Economic Studies, pp. 1-19. At <https://www.eib. org/attachments/efs/infrastructure_investment_in_the_western_balkans_ en.pdf>, accessed 1 August 2020.

IMF. (2015). The Western Balkans: 15 Years of Economic Transition, Regional Economic Issues Special Report, p. 108. At <https://www.imf.org/external/ pubs/ft/reo/2015/eur/eng/erei0315.htm>, accessed 2 July 2020.

Jusufi, G. and Ajdarpašić, S. (2020). The Impact of EU Programmes on Financing Higher Education Institutions in Western Balkans - Evidence from Kosovo. LEXONOMICA Journal of Law and Economics, 12 (1), pp. 107-128. At <https://journals.um.si/index.php/lexonomica/article/view/530>, accessed 2 July 2020.

Jusufi, G. and Bellaqa, B. (2019). Trade Barriers and Exports between Western Balkan Countries. Naše gospodarstvo/Our Economy, 65 (4), pp. 72-80. At <http://www.ng-epf.si/index.php/ngoe/article/view/219>, accessed 31 July 2020.

Jusufi, G. and Lubeniqi, G. (2019). An Overview of Doing Business in Western Balkan: The Analysis of Advantages of Doing Business in Kosovo and North Macedonia. ILIRIA International Review, 9(2), pp. 167-180. At < https://www. iliriapublications.org/index.php/iir/article/view/512>, accessed 30 July 2020.

Jusufi, G. and Ukaj, M. (2020). Migration and Economic Development in Western Balkan Countries: Evidence From Kosovo, Poslovna izvrsnost/ Business excellence, 14 (1), pp. 135-158. At <https://hrcak.srce.hr/index. php?show=clanak\&id_clanak_jezik=347272>, accessed 21 July 2020.

Kadriu, A. et al. (2018). Innovative firms in transition economies: what do they have in common? International Journal of Technology Transfer and Commercialisation, 16 (2), pp. 183-185. At <https://www.researchgate.net/ publication/330551148_Innovative_firms_in_transition_economies_what_ do_they_have_in_common>, accessed 13 July 2020.

Korkmaz, S. et al. (2015). The impact of direct and indirect taxes on the growth of the Turkish economy. Public Sector Economics, 43 (3), pp. 311-323. At 
<http://www.pse-journal.hr/en/archive/the-impact-of-direct-and-indirecttaxes-on-the-growth-of-the-turkish-economy_4564/>, accessed 19 July 2020.

Krasniqi, A.B. and Tullumi, M. (2013). What perceived success factors are important for Small Business Owners in a transition economy? International Journal of Business and Management Studies, 5 (2), pp. 21-30. At <https:// dergipark.org.tr/en/download/article-file/255780>, accessed 10 July 2020.

Krasniqi, B. and Ahmetbasić, J. (2019). Barriers to cross-border trade in intermediate goods within regional value chains in the CEFTA region. LSEE, Research Paper No. 1, pp. 1-21. At <https://www.researchgate.net/ publication/337195235_LSEE CEFTA_Research_Papers_on_International_ Trade_Barriers_to_cross-border_trade_in_intermediate_goods_within_ regional_value_chäins_in_the_CËFTA_region.>, accessed 10 July 2020.

Krešić, A. et al. (2017). Firm performance and obstacles to doing business in the Western Balkans. EBRD, pp. 1-18. At <https://www.ebrd.com/home>, accessed 20 July 2020.

Kryeziu, R. (2019). Role of Tax Regulations in the Republic of Kosovo, Countries of the Balkans and the European Union, in determining Tax Policy. Journal of Economics, Finance and Accounting, 6(2), pp. 63-71. At <https://dergipark. org.tr/tr/download/article-file/747394>, accessed 15 October 2020.

Kukanja, M. and Planinc, T. (2018). Efficiency Analysis of Restaurants in a Small Economy after the Implementation of Fiscal Cash Registers: The Case of Slovenia. Organizacija, 51 (4), pp. 239-250. At <http://organizacija.fov.unimb.si/index.php/organizacija/article/view/896>, accessed 15 June 2020.

Leitner, M.S. (2015). Financing constraints and firm growth in the NMS-10 and the Western Balkan countries - A comparative analysis. The wiiw Balkan Observatory working paper, 115. At <https://wiiw.ac.at/firm-growth-andfinancing-constraints-in-the-nms-10-and-the-western-balkan-countries--acomparative-analysis-dlp-3897.pdf>, accessed 30 June 2020.

Lešnik, T. et al. (2018). VAT Gap Dependence and Fiscal Administration Measures. Naše gospodarstvo, 64 (2), pp. 43-51. At <http://www.ng-epf.si/index.php/ ngoe/article/view/169>, accessed 30 July 2020.

Lorena, Š. (2010). Transition Process in the Western Balkans: How Much Successful Is This Story?. Intelligent Information Management, 2, pp. 243252. At <https://pdfs.semanticscholar.org/95c4/07a534f6ea2529ae4b35f8f8 ec840d0de824.pdf>, accessed 30 July 2020.

Mach. (2018). VAT Rates and their Impact on Business and Tax Revenue. European Research Studies Journal, XXI (1), pp. 144-152. At <https://core. ac.uk/download/pdf/158809282.pdf>, accessed 27 July 2020.

Mahmutaj, R.L. and Krasniqi, A.B. (2020). Innovation types and sales growth in small firms: Evidence from Kosovo. South East European Journal of Economics and Business, 15 (1), pp. 27-39. At <http://journal.efsa.unsa.ba/ index.php/see/article/view/1183>, accessed 24 July 2020.

Matarirano, O. et al. (2019). Tax compliance costs and small business performance: Evidence from the South African construction industry, South African Journal of Business Management 50(1). At <https://www.researchgate. net/publication/333331923_Tax_compliance_costs_and_small_business performance_Evidence_from_the_South_African_construction_industry/ link/5ce74fc692851c4eabba2548/download>, accessed 20 July 2020.

Manzo, M. (2011). Corporate Taxation and SMEs: The Italian Experience. OECD Taxation Working Papers No. 6. At <https://www.oecd-ilibrary.org/ docserver $/ 5 \mathrm{~kg} 3 \mathrm{~h} 0$ th7t7 c-en.pdf?expires=1601746971\&id=id\&accname=gu 
est\&checksum=F8CC35A89677627165E758FF220D283E>, accessed 18 July 2020.

Ministry for Foreign Affairs of Finland, and UNDP. (2014). Impact of Tax Regime on Four Manufacturing Sectors. At <www.undp.org>, accessed 31 July 2020.

Mungaya, M. et al. (2012). Study of Tax System Impact on the Growth of Small and Medium Enterprises (SMEs): With Reference to Shinyanga Municipality, Tanzania. International Journal of Management \& Business Studies, 2 (3), pp. 99-105. At <http://www.ijmbs.com/23/mika.pdf>, accessed 3 July 2020.

Nizaeva, M. and Coşkun, A. (2018). Determinants of the Financing Obstacles Faced by SMEs: An Empirical Study of Emerging Economies. Journal of Economic and Social Studies, 7(2), pp. 81-94. At <https://omeka.ibu.edu.ba/ items/show/127/>, accessed 5 July 2020.

OECD/ETF/EU/EBRD (2019), SME Policy Index: Western Balkans and Turkey 2019: Assessing the Implementation of the Small Business Act for Europe, SME Policy Index, OECD Publishing, Paris. At <https://www.oecd.org/publications/ sme-policy-index-western-balkans-and-turkey-2019-g2g9fa9a-en.htm>, accessed 8 July 2020.

Oke, M.O. (2013). Budget Implementation and Economic Growth in Nigeria. Developing Country Studies, 3 (13), pp. 1-6. At <https://iiste.org/Journals/ index.php/DCS/article/view/9408/9630>, accessed 7 July 2020.

Osmani, R. (2014). Fiscal Decentralization in the Western Balkan Countries, The Case of the Republic of Macedonia. Mediterranean Journal of Social Sciences, 5 (13), pp. 2. At <https://www.mcser.org/journal/index.php/mjss/article/ view/3593/3532>, accessed 22 July 2020.

Osmani, R. (2015). Improved Business Climate and FDI in the Western Balkans. Journal of Economic and Social Studies, 6 (1), pp. 5-21. At <https://core. ac.uk/download/pdf/153449487.pdf>, accessed 21 July 2020.

Peci, B. (2013). Reform of Kosovo Tax System after Independence and its key functions. ILIRIA International Review, 3 (2), pp. 69-82. At <http://iliriapublica tions.org/index.php/iir/article/view/116>, accessed 11 October 2020.

Peci, B. (2016). Tax Incentives in Kosovo Tax System. Acta Universitatis Danubius, Economica, 12 (4), pp. 233-239. At <http://journals.univ-danubius.ro/index. php/oeconomica/article/view/3436/3519>, accessed 1 August 2020.

Pope, J. and Abdul-Jabbar, H. (2008). Tax Compliance Costs of Small and Medium Enterprises in Malaysia: Policy Implications. Curtin University of Technology. At <https://www.researchgate.net/publication/228916705_Tax_Compliance_ Costs_of_Small_and_Medium_Enterprises_in_Malaysia_Policy_Implications>, accessed 2 Augūst $20 \overline{2} 20$.

Qorraj, G. and Jusufi, G. (2018). The EU Stabilisation and Association Agreement for the Western Balkans: Between Challenges and Opportunities. Croatian International Relations Review - CIRR, 24 (81), pp. 51-68. At <https://hrcak. srce.hr/index.php?show=clanak\&id_clanak_jezik=294497> , accessed 3 August 2020.

Qorraj, G. and Jusufi, G. (2019). EU vs Local Market Orientation: Western Balkan Entrepreneurs' Challenge. Entrepreneurial Business and Economics Review, 7(4), pp. 21-32. At <https://eber.uek.krakow.pl/index.php/eber/article/ view/572>, accessed 25 July 2020.

Qorraj, G. (2018). Towards European Union or Regional Economic Area: Western Balkans at Crossroads. Naše gospodarstvo/Our Economy, 64 (1), pp. 11-17. At <http://www.ng-epf.si/index.php/ngoe/article/view/161>, accessed 25 July 2020. 
Rehman, U.N. et al. (2019). Barriers to growth of SMEs in Western Balkan countries. Journal of Management Development, 38 (1). At <https://www. researchgate.net/profile/Naqeeb_Rehman2/publication/281769356_ Drivers_of_firms\%27_growth_a_case_study_of_software_firms_in_

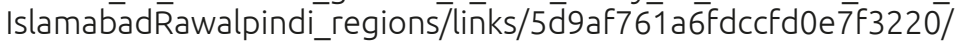
Drivers-of-firms-growth-a-case-study-of-software-firms-in-IslamabadRawalpindi-regions.pdf>, accessed 16 July 2020.

Riinvest Institute. (2016). Economic Potentials in Region Centre. Financed by: The European Union Office in Kosovo, pp. 49. At <https://www. riinvestinstitute.org/uploads/files/2016/September/20/Economic Potentials_in_Region_Center1474371110.pdf>, accessed 13 July 2020.

Ruchkina, G. et al. (2017). Small and medium enterprises in regional development and innovations. Journal of International Studies, 10 (4), pp. 259-271. At <https://www.jois.eu/files/20_462_Ruchkina\%20et\%20al.pdf>, accessed 7 July 2020.

Sanfey, P. and Milatovic, J. (2018). The western Balkans in transition: Diagnosing the constraints on the path to a sustainable market economy. Background paper for the Western Balkans Investment Summit, hosted by the EBRD. At <https://www.ebrd.com/home>, accessed 7 July 2020.

Shevchuk, V. and Kopych, R. (2018). Assessing the Fiscal Sustainability in Ukraine: TVP and VAR/VEC approaches. Entrepreneurial Business and Economics Review, 6 (3), pp. 73-87. At <https://eber.uek.krakow.pl/index.php/eber/ article/view/350>, accessed 9 July 2020.

Sivalingam, T. and Bhaskaran, E. (2005). Impact of VAT on SME Sector. Conference: Seminar on VATAt: Erode Arts College, Tamil Nadu Volume: article published in proceedings, pp. 18-19. At <https://www.researchgate. net/publication/290447389_Impact_of_VAT_on_SME_Sector>, accessed 11 July 2020.

Statovci, B. and Asllani, G. (2017). Fiscal Policy of Kosovo, Taxation and Reforms. International Journal of Management Excellence, 9 (3), pp. 1127-1131. At $<$ https://www.researchgate.net/publication/319874589_Fiscal_Policy_of_ Kosovo_Taxation_and_Reforms>, accessed 14 July 2020.

Syka, Xh. and Kaduku, I. (2013). Correlation between Government and Economic Growth- Fiscal Policy during the Transition in Albania. ILIRIA International Review, 3 (2), pp. 149-162. At <http://iliriapublications.org/index.php/iir/ article/view/121>, accessed 10 July 2020.

Tax Administration of Kosovo. (2020). Tax Types in Kosovo. At <http://www. atk-ks.org/en/portfolio/informata-te-pergjithshme-per-tatimet-ne-kosove/>, accessed 19 July 2020.

Tee, E. et al. (2016). The Effect of Tax Payment on the Performance of SMEs: The Case of Selected SMEs in Ga West Municipal Assembly. European Journal of Business and Management, 8 (20), pp. 119-125. At <https://www.iiste.org/ Journals/index.php/EJBM/article/view/31660/32532>, accessed 31 July 2020.

Tošović-Stevanović, A. and Ristanović, V. (2016). Regional Development in the Western Balkans through the support of EU projects. Megatrend revija/ Megatrend Review, 13 (2), pp. 175-188. At <https://scindeks-clanci.ceon.rs/ data/pdf/1820-3159/2016/1820-31591602175T.pdf>, accessed 21 July 2020.

Tung, L.T. (2018). The effect of fiscal deficit on economic growth in an emerging economy: Evidence from Vietnam. Journal of International Studies, 11(3), pp. 191-203. At <https://www.jois.eu/?456,en_the-effect-of-fiscal-deficit- 
on-economic-growth-in-an-emerging-economy-evidence-from-vietnam>, accessed 21 July 2020.

Twesige, D. and Gasheja, F. (2019). Effect of tax incentives on the growth of SMEs in Rwanda: A case study of SMEs in Nyarugenge district. International Journal of Advanced Educational Research, 4 (3), 39-47. At <http://www. educationjournal.org/>, accessed 21 July 2020.

Uvalić, M. and Cvijanović, V. (2018). Towards A Sustainable Economic Growth and Development in the Western Balkans. A New Economic Agenda for Southeast Europe, Max Brändle and Michael Weichert (Eds.), Zagreb, pp. 13-35. At <https://library.fes.de/pdf-files/bueros/kroatien/14688.pdf >, accessed 29 July 2020.

Velnampy, T. and Achchuthan, S. (2013). Fiscal Deficit and Economic Growth: A Study on Sri Lankan Economic Perspective. Developing Country Studies, 3(3), pp. 166-174. At <https://papers.ssrn.com/sol3/papers.cfm?abstract id=2445760>, accessed 29 July 2020.

Vidovic, H. et al. (2011). Developing Efficient Activation Approaches and Identifying Elements for Regional Cooperation in the Western Balkans. The Vienna Institute for International Economic Studies (wiiw) and ÖSB Consulting GmbH, Vienna, Research Reports, p. 374. At <https://www.wiiw. ac.at/developing-efficient-activation-approaches-and-identifying-elementsfor-regional-cooperation-in-the-western-balkans-dlp-2385.pdf>, accessed 20 July 2020.

Wadesango, N. et al. (2018). Tax Compliance of Small and Medium Enterprises through the Self-Assessment System: Issues and Challenges. Academy of Accounting and Financial Studies Journal, 22 (3). At <https://www. abacademies.org/articles/literature-review-on-the-impact-of-selfassessmentsystem-on-compliance-levels-of-small-and-medium-enterprises-casestudyvan-sales-7289.html>, accessed 21 July 2020.

World Bank Group. (2020). Western Balkans Regular Economic Report: The Economic and Social Impact of COVID-19, No. 17. At <https://www. worldbank.org/en/region/eca/publication/western-balkans-regulareconomic-report>, accessed 1 July 2020.

World Bank. (2014). Kosovo Public Finance Review: Fiscal Policies for a Young Nation. Report No: ACS9351, p. 27. At <https://www.researchgate.net/ publication/277892319_Kosovo_Public_Finance_Review_Fiscal_Policies_ for_a_Young_Nation>, accessed 20 June 2020.

Yusuph, M. and Youze, O.M. (2014). Fiscal and Monetary Policies: Challenges for Small and Medium Enterprises (SMEs) Development in Tanzania. International Journal of Social Sciences and Entrepreneurship, 1(10), pp. 1-12. At <https:// www.ijsse.org/articles/ijsse_v1_i10_305_320.pdf>, accessed 23 June 2020.

Zhllima, E. et al. (2013). Impact of Fiscal Policies on Inputs and Production costs In Greenhouse in Albania. Journal of Central European Agriculture, 14 (2), pp. 109-125. At <https://hrcak.srce.hr/index.php?show=clanak\&id_clanak_ jezik=153107>, accessed 25 June 2020.

2020 Index of Economic Freedom. Contry Rankings. At <https://www.heritage. org/index/>, accessed 30 June 2020. 